\title{
Studi Kualitatif Persepsi Masyarakat Desa Tentang Program Perencanaan Persalinan dan Pencegahan Komplikasi (P4K)
}

\author{
Shindy Ayu W' $\mathbf{1}^{\mathbf{1}}$ Dwi Izzati B ${ }^{2}$, Atikah ${ }^{3}$ \\ 1,2,3 Universitas Airlangga, Jl. Mayjen prof.Dr. Moestopo 47 Surabaya 60131 Telp. 031-5020251, 5030252-3 psw 161 \\ Surabaya, Indonesia
}

\begin{tabular}{l}
\hline ARTICLE INFORMATION \\
\hline Article Trace \\
Submission: June 21, 2018 \\
Final Revision: August 13, 2018 \\
Available online: October 20, 2018 \\
\hline
\end{tabular}

Key Word :

Perception, natal planning,

Contact:

Shandyayugmail.com

\begin{abstract}
A B S T R A K
P4K merupakan salah satu upaya pemerintah dalam menurunkan Angka Kematian Ibu (AKI). Masalah yang ditemukan yakni partisipasi masyarakat yang rendah akan P4K. Penelitian ini bertujuan untuk mengetahui bagaimana persepsi masyarakat tentang program perencanaan persalinan dan pencegahan komplikasi $(\mathrm{P} 4 \mathrm{~K})$. Metode: Penelitian ini merupakan studi kualitatif dengan menggunakan tehnik purposive sampling dalam memilih sample. Sample yang digunakan sebanyak 21 orang yang sudah memenuhi kriteria sample. Data diambil melalui wawancara mendalam dan FGD (Focus Group Discussion). Data dianalisis melalui beberapa tahap yakni reduksi data, transkrip data, penyajian data, pengkodean, kategorisasi dan kesimpulan. Hasil: 1)Sebagian besar informasi $\mathrm{P} 4 \mathrm{~K}$ yang didapatkan responden dinilai masih kurang. 2)Persepsi responden terhadap pelaksanaan P4K mengungkapkan bahwa program belum menjangkau sasaran. 3)Mayoritas responden berpersepsi distribusi stiker P4K dikalangan ibu kurang merata dan sebagian besar ibu hamil memiliki persepsi bahwa kegiatan tersebut tidak ada manfaat bagi dirinya.4) Responden lebih dominan memiliki persepsi ambulans desa sebagai kendaraan motor roda empat layaknya ambulans biasanya. 5)Belum tersedianya fasilitas penunjang $\mathrm{P} 4 \mathrm{~K}$ di desa yakni dasolin/tabulin dan pengelolaan donor darah. Kesimpulan: persepsi masyarakat desa tentang P4K selama ini baik mengenai informasi seputar program maupun pelaksanaannya masih dirasa kurang optimal, sebab sosialisasi tidak dilakukan secara menyeluruh ke masyarakat. Oleh karena itu, perlu adanya kerjasama yang baik antara lintas sektor masyarakat, institusi kesehatan dan pemerintah desa
\end{abstract}

\section{A B S T R A C T}

$\mathrm{P} 4 \mathrm{~K}$ is one of the government's efforts to reduce Maternal Mortality Rate (MMR). The problem found was low community participation in P4K. This study aims to find out how people's perceptions about birth planning and complications prevention ( $\mathrm{P} 4 \mathrm{~K})$ programs. Method: This research is a qualitative study using purposive sampling technique in selecting samples. The samples used were 21 people who had met the sample criteria. Data was collected through in-depth interviews and FGD (Focus Group Discussion). Data were analyzed through several stages namely data reduction, data transcripts, data presentation, coding, categorization and conclusions. Results: 1) Most of the P4K information obtained by respondents was considered to be lacking. 2) Respondents' perception of the implementation of $\mathrm{P} 4 \mathrm{~K}$ revealed that the program had not yet reached the target. 3) The majority of respondents perceive the distribution of $\mathrm{P} 4 \mathrm{~K}$ stickers among mothers as uneven and the majority of pregnant women have a perception that the activity has no benefit for themselves.4) Respondents are more dominant in the perception of village ambulances as four-wheeled motor vehicles as usual ambulances. 5) P4K supporting facilities in the village are not yet available namely dasolin / tabulin and blood donor management. Conclusion: the perception of the village community about $\mathrm{P} 4 \mathrm{~K}$ so far both about information about the program and its implementation is still considered to be less than optimal, because socialization is not carried out thoroughly to the community. Therefore, there is a need for good collaboration between community sectors, health institutions and village governments 


\section{PENDAHULUAN}

Setiap saat seorang ibu dapat meninggal dunia ketika menjalani masa kehamilan, masa persalinan maupun masa nifas. Pada tahun 2016, WHO mencatat rata - rata Angka Kematian Ibu (AKI) di Indonesia sebesar 126/100.000 kelahiran hidup. Hal ini terbilang cukup tinggi jika dibandingkan negara ASEAN lainnya seperti Thailand dan Singapura dengan rata rata AKI dibawah 20/100.000 kelahiran hidup (WHO, 2016a). Walaupun demikian, Indonesia mengalami penurunan jumlah AKI jika dibandingkan dengan perolehan rata - rata AKI pada tahun 2015 yaitu 305/100.000 kelahiran hidup (Widoyono, 2016).

Tentunya perolehan tersebut tidak luput dari kerja keras pemerintah dan masyarakat dalam mendukung terwujudnya MDG's 2015. Salah satu provinsi yang berhasil mencapai target dari MDG's ialah Jawa Timur dengan perolehan rata - rata AKI pada tahun 2015 sebesar 89,60/100.000 kelahiran hidup (Dinkes Prov. Jawa Timur, 2015). Sayangnya, pada tahun 2016 rata - rata AKI Jawa Timur mengalami peningkatan menjadi 91/100.000 kelahiran hidup. Zuhaida menyatakan dalam forum bahwa beberapa kabupaten di Jawa Timur masih memberikan sumbangan jumlah AKI yang cukup besar, termasuk Kabupaten Sidoarjo yang menempati urutan ke-3 yang mana pada tahun 2017 ditemukan 30 kasus ibu hamil meninggal, sedangkan pada Januari 2018 tercatat 5 kasus ibu hamil meninggal dunia (Anonim, 2018). Maka dari itu, pemerintah meningkatkan pelaksanaan berbagai program - program yang dibentuk sebelumnya guna menekan laju pembesaran AKI di Indonesia. Salah satunya melalui Program Perencanaan Persalinan dan Pencegahan Komplikasi (P4K). Dimana strategi penurunan AKI yang diusung meliputi peningkatan cakupan dan kualitas pelayanan kesehatan ibu, peningkatan peran pemerintah dan swasta dalam menyediakan sumber daya, dan pemberdayaan keluarga dan masyarakat (USAID, 2013). Menurut Faiza (2016) dan Nurmala (2015) melalui penelitiannya menyatakan bahwa $\mathrm{P} 4 \mathrm{~K}$ yang dilaksanakan dengan baik memberikan pengaruh yang besar dalam upaya penurunan AKI di masyarakat. Pengaruh yang dimaksud ialah persepsi yang dimiliki ibu hamil dalam merencanakan persalinan yang aman dan nyaman sesuai dengan kondisi dirinya (Ruwayda, 2015).

Dalam merencanakan hal tersebut diperlukan dukungan dan bantuan keterlibatan pelaksana $\mathrm{P} 4 \mathrm{~K}$ di desa guna memberikan informasi P4K dan mengarahkan ibu untuk mendapatkan pelayanan yang tepat pula. P4K juga membutuhkan partisipasi masyarakat secara aktif agar pelaksanaan $\mathrm{P} 4 \mathrm{~K}$ berjalan dengan baik. Namun, kenyataannya masih banyak desa di Kabupaten Sidoarjo yang mana ibu hamilnya tidak menempelkan stiker P4K dan tidak memperoleh stiker P4K Salah satunya adalah Desa Ngingas yang terletak di Kecamatan Waru, Sidoarjo.

Padahal, tertempelnya stiker P4K di rumah ibu hamil merupakan salah satu output yang diharapkan dari pelaksanaan $\mathrm{P} 4 \mathrm{~K}$.

Penelitian ini bertujuan untuk mengetahui persepsi masyarakat tentang P4K di Desa Ngingas, Kecamatan Waru, Kabupaten Sidoarjo.

\section{METODE}

Jenis dan desain penelitian menggunakan desain deskriptif eksploratif dengan pendekatan kualitatif. Sample yang digunakan sebanyak 21 orang dimana mewakili pihak yang menjadi sasaran program yakni kepala desa, tokoh masyarakat, tokoh agama, kader, PKK dan ibu hamil. Tehnik sampling pada penelitian ini adalah non-probability sampling dengan jenis sampling yaitu purposive sampling. Lokasi penelitian berada di Desa Ngingas, Kecamatan Waru, Kabupaten Sidoarjo. Pengumpulan data dilakukan melalui wawancara mendalam kepada 6 orang responden (kepala desa, tokoh masyarakat, dan tokoh agama) dan FGD (Focus Group Discussion) kepada 3 kelompok yang beranggotakan masing - masing 5 orang (kader, PKK, dan ibu hamil). Analisis data yang 
dilakukan melalui beberapa tahapan antara lain : reduksi data, transkrip data, penyajian data, pengkodean, kategorisasi dan penarikan kesimpulan.

\section{HASIL}

Hasil pengambilan informasi melalui wawancara secara mendalam dan FGD ditemukan mayoritas responden mengatakan bahwa belum mengetahui ataupun mendengar akan kepanjangan/singkatan dari $\mathrm{P} 4 \mathrm{~K}$, namun beberapa diantaranya mendiskripsikan P4K sebagai program mengenai persalinan.

"Saya sendiri belum mengenal istilah P4K itu sendiri." (TM/1/B2)

"Sebenarnya saya baru tahu istilah itu hari ini yaitu pagi ini dari samean ya. Cuma kalau mendengar singkatannya seperti itu maka menurut saya $P 4 K$ itu sebuah program yang bertujuan untuk bersosialisasikan masyarakat bahwa perencanaan persalinan itu sangat penting agar nanti didalam persalinan tidak terjadi hal yang tidak diinginkan misalnya kematian ibu, anak dan sebagainya..." (TA/1/B1)

"Selama ini belum pernah setahu saya."(TA/2/B2)

"Kalau kepanjangan saya kurang tahu”(TM/3/B1)

"P4K itu kalau nggak salah mengenai persalinan ya." $(P K K / 2 / C)$

Minimnya informasi P4K dikalangan responden kemungkinan disebabkan oleh sosialisasi P4K yang kurang optimal. Adapun pernah dilakukan sosialisasi yang dirasakan responden kurang maksimal dan cenderung diberikan kepada kelompok kader dan PKK .

"Kalau tiap tahunnya sih nggak, tapi artinya pernah..." (KD/B7)

"Ada. Pernah itu kapan hari itu yang kegiatannya sosialisasinya itu di kegiatan posyandu kalau nggak salah sama PKK, sosialisasi masalah P4K ini."(TM/2/B4)

"Ini kalau sosialisasi secara menyeluruh mungkin masih belum ya. Tapi kalau sosialisasi internal disini kan yang lebih eksis kan karena di desa itu adalah....poskesdes terus disitu juga ada posyandu dan juga ada kader - kader PKK yang lain nah biasanya itu lewat situ sosialisasinya...” (TM/3/B3)

"Iyah sering. "(PKK/2/C3)

"Ya tiap pertemuan PKK dan rapat." (PKK/4/5/E2/F3)

Sebagian besar responden menilai bahwa pelaksanaan $\mathrm{P} 4 \mathrm{~K}$ yang terselenggara di desa dirasa belum maksimal. Responden menganggap pemerintah desa maupun instansi kesehatan terkait belum memberikan dukungan penuh dalam penyelenggaraan $\mathrm{P} 4 \mathrm{~K}$ dan kurang melibatkan tokoh masyarakat dalam memberikan sosialisasi, sehingga program hanya terkesan dilakukan oleh kelompok tertentu yaitu PKK atau kader.

"Sebelum ada pembentukan desa siaga, pelaksanaan P4K ya. Boleh dikira belum ada info yang masuk ya artinya warga juga belum tahu..."(KD/B9)

"Dan selama ini untuk pelaksanaan bidang kesehatan masyarakat itu yang menangani PKK dalam arti memiliki keterlibatan langsung itu ibu PKK....” (TM/1/B5)

"Ya kalau boleh bicara jujur sih belum terlalu mengena ke masyarakat khususnya program ini. Karena kan ya itu tadi kan baru masih berjalan beberapa bulan." (TM/2/B15)

"Kalau disini masih taraf tetap kita jalankan ya masih belum optimal karena apa P4K itu punya 4 POKJAnya. Satu ada pendataan, pengadaan ambulan desa, ada dasolin." (PKK/1/B4)

"Ya gak begitu optimal ya. Wong kegiatan ibu hamil yang datang itu cuma berapa gitu. Orang 3. Antisipasinya kurang ada." (K/1/B2)

"Yang saya ketahui tentang adanya program P4K ini ya itu saya kira sifatnya masih apa ya perlu pembenahan ya..." (TM/3B7)

Ketersedian fasilitas penunjang P4K memberikan pengaruh dalam keberlangsungan pelaksanaan P4K itu sendiri. Sebagian besar responden menyatakan di Desa Ngingas masih belum tersedia ambulans desa, kegiatan dasolin/tabulin, dan kegiatan pengelolaan donor darah. Walaupun tidak memiliki ambulans desa, beberapa responden juga mengungkapkan bahwa masyarakat dapat mengalihfungsikan mobil 
siaga sebagai ambulans desa. Persepsi ambulans desa yang ditemukan pada responden yakni kendaraan roda empat (mobil) yang dilengkapi peralatan medis layaknya ambulans pada umumnya.

"Ambulan desa disini belum punya, yang ada memang mobil operasional desa ya bukan dalam bentuk ambulan, tapi seandainya dibutuhkan oleh warga dalam kegiatan itu kan bisa digunakan untuk kepentingan tersebut ya..." (KD/B19)

"Kalau yang untuk kendaraan, sekarang sudah ada kendaraan siaga. Yang diberikan oleh pihak pemkab, kan itu kan juga bisa dipake sewaktuwaktu kalau ada keadaan emergency." (TM/1/B23)

"Kalau desa saja sekarang ada mobil operasional kalau untuk kesehatan seharusnya juga ada lagi seperti ambulan desa seperti itu..." (TM/3/B13)

"Kalau ambulan desanya sih belum ada. Sebenarnya sih tinggal pelaksanaannya saja."(PKK/1/B4)

Salah satu kegiatan dalam pelaksanaan P4K di desa yaitu pemasangan stiker $\mathrm{P} 4 \mathrm{~K}$ di rumah ibu hamil. Responden menyatakan bahwa tertempelnya stiker P4K di rumah ibu hamil belum pernah dijumpai responden sebelumnya. Hal ini menunjukkan respon ibu hamil di wilayah Desa Ngingas belum menunjukkan bentuk positif.f.

\footnotetext{
"Belum , saya belum pernah lihat sih." (KD/B27)

"Saya belum pernah lihat." (TM/1/B28)

“Kayaknya nggak ada mbak.”(TM/2/B33)

"Ouh nggak ada."(TA/1/B24)

"Ya mayoritas tidak ada."(TA/1/B25)

"Nggak tau. Nggak pernah tahu.” (TA/2/B22)
}

Hambatan dijumpai dalam pelaksanaan kegiatan P4K menurut responden yakni kurang adanya partisipasi masyarakat terlebih dari individu yang bersangkutan (ibu hamil) itu sendiri dalam mengikuti kegiatan - kegiatan $\mathrm{P} 4 \mathrm{~K}$ di desa. Partisipasi masyarakat yang rendah akan kegiatan $\mathrm{P} 4 \mathrm{~K}$ merupakan salah satu kemungkinan dampak dari kurang maksimalnya atas pengadaan sosialisasi $\mathrm{P} 4 \mathrm{~K}$ kepada masyarakat, sehingga responden beranggapan bahwa masyarakat kurang merasakan manfaat dari mengikuti kegiatan tersebut. Selain itu, responden juga kegiatan $\mathrm{P} 4 \mathrm{~K}$ yang berlangsung selama ini belum memiliki biaya operasional yang memadai untuk menunjang kegiatan tersebut berjalan secara optimal.

"Sementara yang menjadi hambatan untuk saya dan pihak yang bersangkutan dalam arti ibu - ibu yang hamil itu sendiri." (KD/B23)

"Ya memang apa ya. Sarana dan prasarana ya. Kalau memang sarana dan prasarananya memadai, kan ini untuk termasuk mobil desa itu juga yang terkait sarana dan prasarana." $(T M / 2 / B 30)$

"Ya karena ini kan masyarakatnya agak kolot begitu ya bukan masyarakat perkotaan yang memiliki pemikiran yang terbuka ya ini kan masih agak tertutup, sehingga orang itu masih mempercayai itu apa kebiasaan yang ada di daerah. Terkadang apa lho manfaat dari sosialisasi itu mbayi ya mbayi begitu bahasa jawanya. Orang kalau di masyarakat desa itu seperti itu." (TA/1/B26)

"Ya itu tadi harus melibatkan semua komponen itu mulai awal, sehingga tokoh masyarakat, tokoh agama, tokoh pemuda dan tokoh organisasi itu sebenernya itu harus dilibatkan jangan hanya sekedar kelompok yang hanya membuat kegiatan itu saja. Sehingga kan yang lainnya tidak tahu. Paling bisanya ya cuma kelompok tertentu saja."(TA/2/B17)

"Yang menjadi hambatan kembali lagi terbentur pada biaya. Kalau selama ini kalau kita omongin terbentur ya benturan itu berada pada biaya untuk mengatasi permasalahan yang ada." (TM/3/B14)

"Masalahnya kan hanya itu - itu saja kayak saya ini sudah tidak hamil, kan maksudnya yang menghadiri itu lho. Jadinya kurang respon dianggapnya ya itu - itu saja sekedar informasi saja lebih fokus pada kesehatan yang di lingkup PKK. Bagi ibu PKK yang respon ya disampaikan ke warganya ya yang tidak kurang bisa menyampaikan hal tersebut." (K/5/F5) 


\section{DISKUSI}

\section{A. Persepsi masyarakat tentang P4K}

Hasil penelitian menunjukkan bahwa sebagian besar responden belum memahami atau mengerti akan informasi P4K. Gambaran persepsi yang diperoleh masyarakat mengenai $\mathrm{P} 4 \mathrm{~K}$ yakni program yang berhubungan dengan persalinan. Hal ini menandakan bahwa ada kemungkinan kurang optimalnya pengadaan sosialisasi $\mathrm{P} 4 \mathrm{~K}$ di desa, sehingga infomasi $\mathrm{P} 4 \mathrm{~K}$ yang diterima masyarakat masih sedikit untuk mendeskripsikan bagaimana bentuk program tersebut. Adapun pernah dilakukan sosialisasi menurut beberapa responden sosialisasi hanya diberikan dan diperuntukkan kelompok tertentu yakni kader dan PKK. Dampak dari hal ini menyebabkan rendahnya keterlibatan lintas sektor kemasyarakatan lainnya guna membantu mempercepat penyebaran informasi pada masyarakat. Porawouw (2012) menyatakan bahwa tokoh - tokoh yang memiliki peran penting dalam masyarakat khususnya masyarakat desa cenderung mempunyai kedekatan emosional yang lebih, artinya tokoh tersebut lebih memahami bagaimana kondisi lingkungan di daerahnya. Dimana dapat dipergunakan untuk mempermudah penyampaian informasi $\mathrm{P} 4 \mathrm{~K}$ kepada masyarakat dan menggerakkan masyarakat untuk berpartisipasi secara aktif pada program tersebut.

Keberhasilan dari diadakannya sosialisasi bergantung pada tercapai dan tidaknya tujuan dari sosialisasi itu sendiri. Salah satu tujuan sosialisasi yakni dapat menanamkan nilai dan kepercayaan akan sesuatu kepada individu, sehingga menjadi suatu kebiasaan dalam kehidupan bermasyarakat (Abdullah, 2006). Menurut Marmer (2016) karakteristik pemberi stimulus yang memiliki keselarasan latar belakang sosial dan status sosial yang berbeda (dihormati) di masyarakat mempunyai perananan penting dalam membentuk persepsi pada individu, begitu pula dengan penanaman nilai dan kepercayaan mengenai $\mathrm{P} 4 \mathrm{~K}$ yang dilakukan oleh tokoh masyarakat terhadap masyarakat desa. Oleh karena itu, sosialisasi yang dilakukan pada ruang lingkup yang lebih kecil di lingkungan masyarakat oleh perangkat RT atau RW dirasa lebih efektif dan efisien guna memberikan informasi P4K secara tepat.

\section{B. Persepsi masyarakat tentang pelaksanaan P4K}

Penilaian responden terhadap pelaksanaan P4K mengungkapkan bahwa pelaksanaan P4K yang telah dilakukan di wilayah tempat tinggal mereka dirasa masih belum optimal. Penilaian tersebut kemungkinan dipengaruhi oleh sosialisasi P4K yang masih belum menjangkau seluruh masyarakat desa, sehingga mengakibatkan rendahnya partisipasi masyarakat akan kegiatan P4K di Desa Ngingas. Sebagian besar masyarakat diduga belum mendapatkan informasi yang secara rinci baik mengenai tujuan, manfaat dan pelaksanaannya a. Menurut Nababan (2018) efektivitas dalam penerapan P4K di desa dipengaruhi oleh 4 faktor antara lain: faktor puskesmas, faktor kader, faktor ibu hamil dan faktor lingkungan. Faktor puskesmas yang dimaksud adalah kinerja dan ketersedian tenaga pelaksana yang lebih dikenal POKJA (Kelompok Kerja) yang terdiri dari 4 bagian yaitu pokja penandaan/pendataan, pokja dasolin/tabulin, pokja ambulans desa dan pokja donor darah (Depkes R.I, 2009).

Salah satu kegiatan dalam pokja pendataan/penandaan yakni penandaan stiker P4K di rumah ibu hamil. Sebagian besar responden mengungkapkan belum pernah menjumpai rumah ibu hamil tertempel stiker yang dimaksud. Alasan yang mendasari tidak tertempelnya stiker $\mathrm{P} 4 \mathrm{~K}$ di rumah ibu hamil disebabkan mayoritas ibu hamil tidak memiliki stiker P4K dan adanya persepsi ibu hamil yang menunjukkan kegiatan tersebut kurang bermanfaat untuk dirinya, sehingga mereka enggan untuk menempelkannya. Stiker P4K sendiri memuat informasi - informasi penting ibu meliputi tafsiran persalinan, calon donor darah, trasnsportasi yang digunakan sampai 
dengan tempat bersalin yang diinginkan (Depkes R.I, 2009).

Pokja ambulans desa pada P4K memiliki wewewang dalam mengelola ketersedian ambulans desa saat dibutuhkan ibu hamil dalam mengakses pelayanan kesehatan. Menurut Depkes R.I (2009) definisi ambulans desa adalah kendaraan yang mampu mengantar calon ibu ke pelayanan kesehatan terdekat guna mendapatkan pertolongan segera dan dikelola oleh masyarakat seperti mobil, ojek,becak, dll. Namun, hal ini berbeda dengan persepsi yang diterima masyarakat tentang ambulans desa yakni kendaraan roda empat (mobil) yang dilengkapi peralatan medis seperti ambulans pada umumnya, sedangkan untuk pokja tabulin/dasolin dan pokja donor darah masih belum tersedia di Desa Ngingas.

Faktor kader yang mempengaruhi pelaksanaan P4K bergantung dari seberapa besar kader menjalankan perannya pada P4K. Adapun peran kader pada P4K menurut Mikrajab dan Rahmawati (2012) yakni membantu bidan terutama bidan desa setempat dalam pendataan ibu hamil, melakukaan PWS KIA, penimbangan ibu hamil, memasang stiker P4K, dst. Kenyataan yang ditemukan dilapangan sebagian besar kader Desa Ngingas memiliki jabatan lain pada kepengurusan organisasi kemasyarakatan lainnya dan beban kerja yang cukup tinggi, sehingga menyebabkan kader kurang aktif dalam menjalankan peranannya. Selain itu, rekontruksi kepengurusan P4K yang terjadi pada tahun 2017 juga kemungkinan menjadi salah satu penyebab dari penyelenggaraan $\mathrm{P} 4 \mathrm{~K}$ yang kurang optimal. Faktor ibu hamil dalam pelaksanaan $\mathrm{P} 4 \mathrm{~K}$ yang dimaksud meliputi pengetahuan ibu hamil mengenai $\mathrm{P} 4 \mathrm{~K}$, persepsi dan sikap ibu hamil terhadap pelaksanaan P4K. Mayoritas ibu hamil yang ditemukan memiliki pengetahuan yang kurang akan informasi P4K. Hal ini sejalan dengan penelitian yang dilakukan Aliyanto dan Rosmadewi (2014) yang mengungkapkan bahwa promosi P4K yang sering dilakukan di lapangan belum mengoptimalkan pengetahuan ibu terhadap P4K. Walaupun demikian, bidan dan pelaksana $\mathrm{P} 4 \mathrm{~K}$ tetap harus memberikan penyuluhan tersebut guna membantu ibu mempersiapkan persalinan yang tepat, aman dan nyaman. Pengetahuan yang diterima ibu mempengaruhi bagaimana persepsi dan sikap ibu akan P4K dibentuk. Persepsi ibu mengenai P4K dipengaruhi seberapa sering ibu terpapar informasi tersebut melalui kunjungan antenatal atau kunjungan rumah yang dilakukan bidan/kader (Ma'arif, 2018). Persepsi yang terbentuk akan menentukan pengambilan sikap ibu dalam merencanakan persalinannya. Hasil penelitian dari Debelew, et. al (2014) menyatakan bahwa sikap positif yang diberikan ibu dalam perencanaan persalinan dan pencegahan komplikasi dapat meningkatkan kemungkinan persiapan persalinan secara signifikan pula. Walaupun, P4K memiliki respon yang positif di kalangan ibu hamil, akan tetapi sebagian besar ibu hamil di Desa Ngingas belum berpartisipasi dalam kegiatan $\mathrm{P} 4 \mathrm{~K}$ contohnya saja penempelan stiker $\mathrm{P} 4 \mathrm{~K}$ di rumah mereka.

Salah satu faktor lingkungan yang mempengaruhi pelaksanaan $\mathrm{P} 4 \mathrm{~K}$ yaitu partisipasi masyarakat. Keikutsertaan masyarakat dalam setiap kegiatan P4K belum mendapatkan respon positif, sebab masyarakat memiliki persepsi bahwa kegiatan $\mathrm{P} 4 \mathrm{~K}$ hanya dikhususkan bagi ibu hamil. Selain itu, beberapa responden menyatakan bahwa alasan yang mendukung rendahnya partisipasi masyarakat yakni pengadaan kegiatan yang cenderung pada jam kerja dan lokasi yang terbilang cukup jauh dari tempat tinggal ibu, sehingga masyarakat yang tidak bisa hadir dalam kegiatan. Sebagian besar masyarakat juga memiliki persepsi bahwa informasi dan keikutsertaan dalam pelaksanaan P4K dianggap kurang penting, sehingga masyarakat lebih mengenyampingkan kegiatan tersebut. Menurut Mandasari dan Maesaroh (2016) pada penelitiannya menyebutkan bahwa adanya persepsi masyarakat yang baik akan sesuatu hal akan memberikan dampak positif berupa partisipasi masyarakat yang baik pula. Oleh karena itu, perubahan persepsi masyarakat mengenai $\mathrm{P} 4 \mathrm{~K}$ melalui sosialisasi yang maksimal kepada seluruh masyarakat Desa 
Ngingas sangatlah penting untuk dilakukan, agar masyarakat paham dan berkontribusi dalam upaya menurunkan angka kematian ibu dan bayi di wilayahnya masing - masing.

Setiap menjalankan suatu program tentunya ditemukan suatu hambatan dalam pelakasanaannya, termasuk pelaksanaan $\mathrm{P} 4 \mathrm{~K}$ di Desa Ngingas. Hambatan utama pada penyelengaraan kegiatan P4K di Desa Ngingas yaitu adanya kesulitan pelaksana $\mathrm{P} 4 \mathrm{~K}$ dalam memotivasi masyarakat untuk mengikuti kegiatan P4K dan kurangnya bantuan dana guna menunjang operasional kegiatan P4K. Hal ini dibenarkan oleh Mariani (2013) pada penelitiannya yang menunjukkan bahwa pelaksanaan P4K yang selama ini berlangsung di masyarakat baik berupa promosi sampai dengan kunjungan rumah yang dilakukan bidan ditunjang dari BOK (Biaya Operasional Kegiatan) puskesmas setempat, yang mana BOK yang tersedia masih dianggap kurang untuk memfasilitasi pelaksanaan P4K. Maka dari itu, diperlukan dukungan masyarakat setempat dan pemerintah desa dalam mengelola kegiatan tersebut, sehingga tujuan dari penyelengaraan P4K itu sendiri dapat tercapai

\section{KESIMPULAN}

Persepsi masyarakat akan P4K secara garis besar berupa program yang hanya berhubungan dengan persalinan. Sebagian besar masyarakat belum mampu mendeskripsikan bagaimana bentuk dari $\mathrm{P} 4 \mathrm{~K}$ itu sendiri karena minimnya informasi P4K baik itu berupa definisi, manfaat maupun tujuan dari pelaksanaan kegiatan tersebut. Fasilitas penunjang $\mathrm{P} 4 \mathrm{~K}$ yang baru tersedia di Desa Ngingas saat ini adalah mobil siaga yang dapat beralih fungsi sebagai ambulans desa, akan tetapi masyarakat lebih dominan berpersepsi bahwa ambulans desa merupakan kendaraan roda empat (mobil) layaknya ambulans pada umumnya, sehingga masyarakat beranggapan belum tersedia ambulans desa di wilayah mereka, sedangkan wadah kegiatan dasolin/tabulin dan donor darah masih belum tersedia. Masyarakat di Desa
Ngingas juga memiliki persepsi bahwa sosialisasi dan pelaksanaan kegiatan $\mathrm{P} 4 \mathrm{~K}$ hanya diperuntukkan ibu hamil saja, sehingga partisipasi masyarakat dalam mendukung kegiatan tersebut terbilang cukup rendah. Selain itu, mayoritas ibu hamil di Desa Ngingas tidak memiliki stiker P4K dan sebagian besar lainnya memiliki persepsi yang kurang positif akan manfaat stiker P4K sehingga enggan untuk menempelkannya di rumah mereka.

Sebaiknya pada penelitian selanjutnya diharapkan dapat lebih banyak mengulas akar akar permasalahan pelaksanaan P4K yang terjadi di wilayah Indonesia baik di daerah pedesaan maupun perkotaan melalui pendekatan kualitatif seperti halnya persepsi suami dari ibu hamil, persepsi daei pihak instansi yang terkait yaitu pihak pemerintah di tingkat kecamatan, pihak puskesmas maupun pihak di tingkat kabupaten mengenai $\mathrm{P} 4 \mathrm{~K}$, dan pengaruh persepsi kader dan PKK dalam meningkatkan jumlah partisipan kegiatan P4K, dsb. Selain itu, diharapkan masyarakat, pemerintah di tingkat sektor desa sampai dengan kabupaten, tenaga kesehatan dan instansi kesehatan dapat bekerjasama dengan baik untuk mendukung keberlangsungan penyelenggaran kegiatan $\mathrm{P} 4 \mathrm{~K}$ yang sudah dibentuk secara optimal sesuai dengan pedoman Depkes R.I. tahun 2009.

\section{REFERENSI}

Abdullah, M. W. (2006). sosiologi. Jakarta: Grasindo. Retrieved from https://books.google.co.id/books?id=09G ZV1VfzVQC

Aliyanto, W., \& Rosmadewi. (2014).

Pengetahuan Ibu Hamil Tentang Program Perencanaan Persalinan Dan Pencegahan Komplikasi (P4K) Pada Antenatal Care. Jurnal Keperawatan, X(1), 90-96.

Anonim. (2018). Ketua TP-PKK Kabupaten Sidoarjo Ajak Kader PKK Turunkan AKI dan AKB. Retrieved February 23, 2018, from

http://www.sidoarjokab.go.id/index.php?p $=$ read\&id $=1225$ 
Debelew, G. T., Mesganaw, F. A., \& Alemayehu, W. Y. (2014). Factors Affecting birth preparedness and complication readiness in Jimma Zone, Southwest Ethiopia. Pan African Medical Journal. Retrieved from http://www.panafrican-medjournal.com/content/article/19/272/full

Depkes R.I. (2009). Pedoman program perencanaan dan pencegahan komplikasi ( $p 4 k$ ) dengan stiker (2009 No. 618.3/Ind/p, 2009th ed.). 2009. Jakarta: Departemen Kesehatan Republik Indonesia. Retrieved from www.depkes.go.id

Dinkes Prov. Jawa Timur. (2015). Profil kesehatan Provinsi Jawa Timur Tahun 2015 (2015th ed.). Jawa Timur: Dinkes Provinsi Jatim. https://doi.org/10.1017/CBO97811074153 24.004

Faiza, R., Notobroto, H. B., Trijanto, B., \& Soedirham, O. (2016). Influence of Prenatal Class to the Practice of P $4 K$ ( Birth Planning and Prevention of Birth Complication). Airlangga University. Airlangga University. Retrieved from http://repository.unair.ac.id/id/eprint/4549 6

Ma'arif, F. (2018). Faktor Yang Mempengaruhi Perencanaan Persalinan dan Pencegahan Komplikasi Oleh Ibu Hamil Trimester III di Puskesmas Ngagelrejo Surabaya. Airlangga University.

Mandasari, N. A., \& Maesaroh. (2016). Pengaruh Partisipasi dan Motivasi Terhadap Partisipasi Masyarakat Desa Hutan Dalam Pengelolaan Hutan Bersama Masyarakat (PHBM) di Kawasan BKPH Guwo. Journal Of Public Policy and Management Review, 5, 1-16. Retrieved from

https:/ejournal3.undip.ac.id/index.php/jpp $\mathrm{mr} /$ article/view/13649

Mariani, P. (2013). Hambatan dalam implementasi program perencanaan persalinan dan pencegahan komplikasi (P4K) di Kabupaten Badung. Public Health and Preventive Medicine Archive
(PHPMA), 1(2), 142-149. Retrieved from http://ojs.unud.ac.id/index.php/phpma/arti cle/view/7870

Marmer, L. W. (2016). Persepsi Terhadap Dukungan Suami Pada Primipara Yang Mengalami Depresi Pasca Melahirkan. Universitas Airlangga.

Mikrajab, M. A., \& Rahmawati, T. (2012). Peran Kader Kesehatan Dalam Program Perencanaan Persalinan Dan Pencegahan Komplikasi Pada Ibu Hamil Di Posyandu Di Kota Mojokerto, Provinsi Jawa Timur. Buletin Penelitian Sistem Kesehatan, $15(4$ Okt), 361-368. https://doi.org/10.1017/CBO97811074153 24.004

Nababan, S. (2018). Efektivitas Program Perencanaan Persalinan dan Pencegahan Komplikasi (P4K) Dalam Penandaan Stiker Ibu Hamil di Kota Surabaya. Airlangga University.

Nurmala, E. Y. I. (2015). Sikap Masyarakat Dalam Upaya Pemberdayaan Masyarakat Pada Program Perencanaan Persalinan dan Pencegahan Komplikasi (P4K) di Kabupaten Malang. STIKES Kendedes Malang. Stikes Kendedes Malang.

Porawouw, R. (2012). Peran Tokoh Masyarakat Dalam Meningkatkan Partisipasi Pembangunan (Studi di Kelurahan Duasudara Kecamatan Ronowalu Kota Bitung). Sosial Dan Politik UNSRAT Manado, 1-17.

Ruwayda. (2015). Persepsi Ibu Hamil Tentang Program Perencanaan Persalinan dan Pencegahan Komplikasi P4K di Kelurahan Tanjung Pinang Kota Jambi Tahun 2014. Jurnal Ilmiah Universitas Batanghari Jambi, 15(1), 127-133.

Suud, F. (2017). Kematian Ibu Melahirkan di Jatim 91/100 Ribu Kelahiran. Retrieved July 31, 2017, from https://duta.co/kematian-ibu-melahirkandi-jatim-91100-ribu-kelahiran/

USAID. (2013). Menuju Tata Kelola Program Perencanaan Persalinan dan Pencegahan Komplikasi, 1-16. Retrieved from http://www.kinerja.or.id/pdf/ee967ac6- 
Studi Kualitatif Persepsi Masyarakat Desa Tentang......

1e5f-41b3-b231-79c1894af469.pdf

WHO. (2016a). GHO | World Health Statistics data visualizations dashboard | Maternal mortality. Retrieved January 1, 2016, from http://apps.who.int/gho/data/node.sdg.3-1viz?lang=en

WHO. (2016b). WHO | Maternal mortality. Retrieved June 20, 2016, from http://www.who.int/mediacentre/factsheet s/fs348/en/

Widoyono, S. B. (2016). Potret Awal Tujuan Pembangunan Berkelanjutan (Sustainable Development Goals) di Indonesia. (A. Said \& I. Budiati, Eds.) (Desember,2). Jakarta: Badan Pusat Statistik Indonesia. Retrieved from www.bps.go.id 